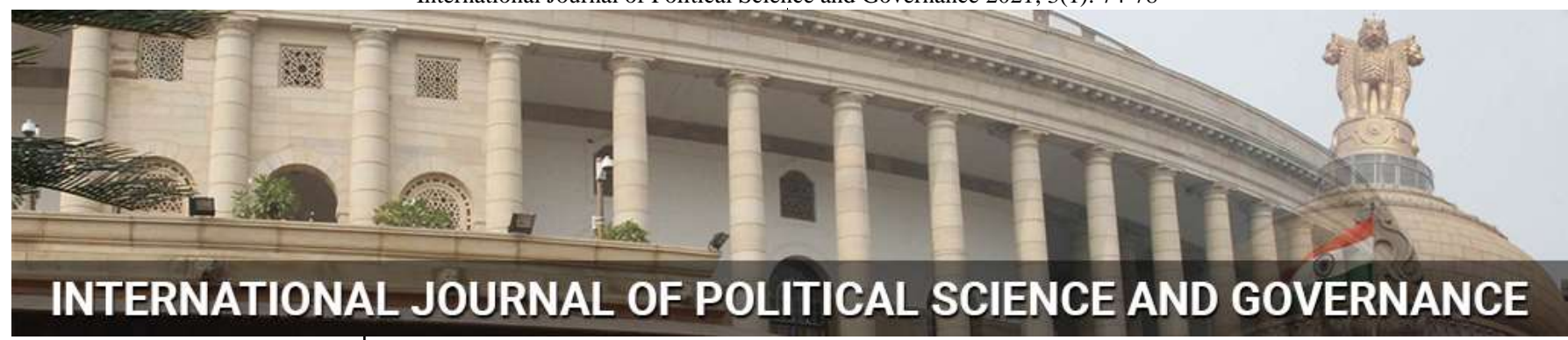

E-ISSN: 2664-603X P-ISSN: 2664-6021 IJPSG 2021; 3(1): 74-78 www.journalofpoliticalscience.com Received: 11-01-2021 Accepted: 02-03-2021

Aashish Kumar Shukla PhD Scholar, Department of Political Science, University of Delhi, Doctoral Fellow, ICSSR, New Delhi, India
Corresponding Author: Aashish Kumar Shukla PhD Scholar, Department of Political Science, University of Delhi, Doctoral Fellow, ICSSR, New Delhi, India

\section{Political resistance to social reforms: The case of uniform civil code in India}

\author{
Aashish Kumar Shukla
}

DOI: https://doi.org/10.33545/26646021.2021.v3.i1b.89

\begin{abstract}
Under the Directive Principles of State Policy in the Indian Constitution, Article 44 directs the State that "The State shall endeavour to secure for the citizens a Uniform Civil Code throughout the territory of India." Apart from this, admissible comments have also been made from time to time by various courts of India. But the Uniform Civil Code demanded for India in the early years of Independence hasn't implemented till date. The Parliament which passed the Hindu Code Bill in 1955-56 as a social reform in Hindu society, the same institution has not been able to implement the Uniform Civil Code till date. Everyone has their own questions and their own arguments on different perspectives of consensus and disagreement on the subject, which has turned it into more of a controversy than an attempt of social reform. In the guise of this controversy, the secular nature of the Indian state has not only questioned but has also been seen as selective secularism or pseudo-secularism.
\end{abstract}

Keywords: Secularism, fundamental rights, social change, religious freedom, equality

\section{Introduction}

70 years ago, the people of India surrendered themselves to the most balanced and inclusive constitution in the world which was committed to the establishment of justice, freedom, equality and fraternity in India. This constitution provides fundamental rights to all citizens of India and also binds them to certain fundamental duties. In the Indian constitution, the right to equality and freedom, there is also a sense of equality between different religions and freedom of different religions. Under the Fundamental Duties, a duty of every citizen has also been told to "create a sense of harmony and equal brotherhood among all the people of India which goes beyond all discrimination based on religion, language and region or class ......". Apart from this, the constitution gives instructions to the citizens as well as the states in certain subjects through the directive elements of the policy of the state. A similar instruction has been given to the State in Article 44 that "the State shall endeavour to obtain a uniform civil code for citizens in all the territories of India". But even after 70 years of the adoption and enactment of the constitution, the Republic of India could not achieve the goal of the inherent equality in the rights, duties and directive elements.

This article will try to analyze by keeping this point at the centre that the Uniform Civil Code that was demanded in the early years of independence, for which reasons it could not be implemented till date? Apart from this, it will also be a matter of investigation in this article that how much of the fundamental rights given in Article 25 have been opposed by keeping the fundamental rights given in the centre, in its nature is justified. Because if this article provides religious freedom, then it also imposes some restrictions to secure public order, morality and health. Apart from this, the family and social reforms that were being talked about for Hindus while bringing the Hindu Code Bill in 1947 were equally needed for the minority class at that time, then what were the circumstances that the Parliament which in 1951 Hindu society Passed the Hindu Code Bill for reform, the Parliament has not been able to implement the same civil code till date? And how was it strongly opposed to the country's secularism? And since then, there has been unwarranted opposition to the issue of the Uniform Civil Code.

Speaking in favour of the Uniform Civil Code, Nirmal Chatterjee said, the legislation that the Nehru Government is supporting to change the Hindu law is communal in its nature. Apart from this, bringing laws against a particular community is also against the fundamental rights to religious freedom provided in the Indian constitution. 
Why is this effort to change the personal laws being made only for Hindus while a Uniform Civil Code has been explicitly provided in the Directive Principles? (Smith, 1967: 286) J. B. Kripalani also endorsed the Uniform Civil Code, saying that if we are a democratic state, then we should not make laws for only one community. Can our government introduce a marriage law for the Muslim community? Will the law minister apply the las of one marriage to all religious communities in India? This is democratic practice. In the form, the House of People is not only communal, the government is also communal ${ }^{[1]}$.

\section{Uniform Civil Code: The Idea}

It is an established fact about India that it is a land of geographical and demographic statistics. It is inhabited by people of diverse religions, cultures and beliefs, who also have their own personal laws, which differ from each other on a large scale. These laws in its nature clarify and regularize the family and social fabric of its members within a society. However, such personal laws are not only contrary to the unity and integrity of India in some form but are also a big challenge for a growing democracy. To some extent human dignity, especially in the context of women, also appears to be afflicted in such laws. Keeping these facts in mind, the framers of the Constitution have provided the Uniform Civil Code in Part-4, Article-44 of the Constitution. This provision directs the state to try to achieve a uniform civil code for all citizens. In addition, the fifth entry of the concurrent list mentioned in the Seventh Schedule of the Constitution also empowers the state in this subject. It is described that:

Marriage and divorce; infants and minors; adoption; wills, intestacy and succession; joint family and partition; all matters in respect of which parties in judicial proceedings were immediately before the commencement of this Constitution subject to their personal law ${ }^{[2]}$.

Thus, the purpose of our democratic system is to eliminate barriers such as creed, caste, creed, etc. and create such methods through which the rule of law can be established in Indian society. In this context, the idea of the Uniform Civil Code cannot be viewed separately from those provisions of the Constitution which provide equality of law and equal protection of law to the citizens of India. This idea becomes more important when the Preamble of the Constitution is committed to provide social, economic and political justice to the people of India.

The idea of the Uniform Civil Code is more social than economic and political. It replaces the individual laws of all religious communities with the aim of enacting a law under which the subjects of family, matrimonial and succession of those communities can be regulated. With this type of legislation, the social discrimination in these communities can be pushed forward.

\section{Constituent Assembly and Uniform Civil Code}

In 1947, the idea of Uniform Civil Code was transmitted to the Constituent Assembly. The Uniform Civil Code was discussed in the Constituent Assembly under the Article Article 35. The Sub-Committee on Fundamental Rights incorporated the Uniform Civil Code into the Directive Elements of State Policy, where it was placed in Article 39.
The Muslim members present in the meeting protested strongly on this subject from the beginning. Mohammed Ismail Khan, a Muslim member of the Constituent Assembly, argued against the Uniform Civil Code:

The right to follow personal law is part of the way of life of those people who are following such laws; it is part of their religion and part of their culture. If anything is done affecting the personal laws, it will be tantamount to interference with the waibidy of life of those people who have been observing these laws for generations and ages. This secular State which we are trying to create should not do anything to interfere with the way of life and religion of the people ${ }^{[3]}$.

Another member of the assembly, Mehboob Ali Beg Sahib Bahadur, argued that it was against the secular state:

People seem to think that under a secular State, there must be a common law observed by its citizens in all matters, including matters of their daily life, their language, their culture, their personal laws. That is not the correct way to look at this secular State. In a secular State, citizens belonging to different communities must have the freedom to practice their own religion, observe their own life and their personal laws should be applied to them ${ }^{[4]}$.

Another member Naziruddin Ahmed urged the state to consider the Uniform Civil Code carefully, stating that:

That this is not a matter of mere idealism. It is a question of stern reality which we must not refuse to face and I believe it will lead to a considerable amount of misunderstanding and resentment amongst the various sections of the country. What the British in 175 years failed to do or was afraid to do, what the Muslims in the course of 500 years refrained from doing, we should not give power to the State to do all at once ${ }^{[5]}$.

In contrast, there were many members in the Constituent Assembly who believed that the implementation of the Uniform Civil Code is a matter of interest of all citizens and not of minorities or majorities. Members of the House K M Munshi said that:

When you want to consolidate a community, you have to
take into consideration the benefit which may accrue to
the whole community and not to the customs of a part of
it. It is not therefore correct to say that such an act is
tyranny of the majority. If you will look at the countries
in Europe which have a Civil Code, everyone who goes
there from any part of the world and every minority, has
to submit to the Civil Code. It is not felt to be tyrannical
to the minority. The point however is this, whether we
are going to consolidate and unify our personal law in
such a way that the way of life of the whole country may
in course of time be unified and secular. We want to
divorce religion from personal law, from what may be
called social relations or from the rights of parties as
regards inheritance or succession ${ }^{[6]}$.

In response to the question of some Muslim members of the House, whether a uniform civil law can be implemented in a large and diverse country like India, Dr. Bhim Rao Ambedkar, Chairman of the Drafting Committee said that: 
We have in this country a uniform code of laws covering almost every aspect of human relationship. We have a uniform and complete Criminal Code operating throughout the country, which is contained in the Penal Code and the Criminal Procedure Code. We have the Law of Transfer of Property, which deals with property relations and which is operative throughout the country. Then there are the Negotiable Instruments Acts: and I can cite innumerable enactments which would prove that this country has practically a Civil Code, uniform in its content and applicable to the whole of the country ${ }^{[7]}$.

After independence, the question of the status of individual religious or sectarian laws got entangled in the vortex of national politics. In the Constituent Assembly, for nearly two years, progressive lawmakers on the subject faced objections from conservative Muslim members present in the House due to their assertions in favour or opposition to the Uniform Civil Code, those who, as spokespersons of the minorities of the country, continuously opposed any such law which in any way affects their individual pantheon laws.

The debate in the Constituent Assembly makes it clear that the framers of the Constitution had a detailed discussion on the concept, relevance and utility of the Uniform Civil Code. Muslim members of the Constituent Assembly and conservative Hindu members vehemently opposed the move. Against this backdrop, the search for an argument for an objective assessment of the Uniform Civil Code in a country full of religious, cultural and linguistic diversity has not ended.

Immediately after India's independence from British imperialism, the followers of the Constitution envisaged the establishment of a sovereign, democratic, republic - based on ideas of justice, freedom, equality and fraternity. In 1976, in the preamble, incorporating the terms 'secularism' and 'socialism', there was an attempt to further the nature of the Indian Republic. The fundamental rights in relation to the right to freedom of religion were included in our constitution before the constitution was enacted in 1950 . Since then, the Constituent Assembly as well as on every platform, has repeatedly discussed individual laws. Even before the enactment of the Constitution, there was a wide debate in the Constituent Assembly, in favour and opposition to individual laws.

\section{Uniform Civil Code and the case of Indian secularism}

The relationship between the religion and state in India could be analysed in a different viewpoint from the idea of western secularism. The latter talks about the separation of state from religion, but India do not accept the western framework of separation, rather it is based on the principle of equal respect to all religious faiths i.e. Sarv Dharm Sambhav. And if there is any distance state maintains, that would be equal. (Mahajan, 2015:36) As the Uniform Civil code is purely a religious issue and Indian state has different stands at different times on this issue, but somewhere it reflects the Indian notion of secularism which gives equal importance to all religions. Implementing the Code will lead all the communities under a common legal umbrella in their civil issues. But everyone has their own questions and arguments on different perspectives of consensus and disagreement on the subject of the Uniform Civil Code, which has turned it into more of a controversy than an attempt at social reform. The secular nature of the Indian state has been continuously questioned not only under the cover of this controversy, but has also been seen as select secularism or pseudo-secularism.

While the Constitution of India gives freedom to all citizens to conscience under Article 25 and to freely practice, conduct and propagate religion, on the other hand, Article 44 instructs the state to make a uniform civil code for all citizens. It speaks of such a 'social legislation', to remove inconsistencies in the personal laws of different religions. But, In the nearly 70 years of independence, India has served to appease a particular community in the name of secularism and through the politics of minoritism. Therefore, considering the Uniform Civil Code as contrary to Article 25 of the Constitution, no meaningful effort was ever made for it. Article 25 of the constitution provides that every citizen has the right to freedom of conscience and free profession, practice and propagation of religion ${ }^{[8]}$. Many scholars who criticize the Uniform Civil Code believe that religion is an individual's personal subject and this law will be an impediment to a person's religious conduct and religious activities. But while making such an argument, they forget that sub-clause-2 (a) of the same article also provides that, "Nothing in this article shall affect the operation of any existing law or prevent the State from making any law regulating or restricting any economic, financial, political or other secular activity which may be associated with religious practice ${ }^{[9]}$.' Apart from this, it has been clarified in this article that a person will follow his religious activities, subject to 'public order, morality and health'. In this context, if we look at the status of women under personal laws, it is not only contrary to morality towards women but also against public order. The Shah Bano case of 1985 , which very clearly highlights the contradiction between women's right to equality and the collective right of the Muslim community (Mohpatra, 2016: 222), also confirms how Muslims Personal law provides for inconsistent provisions against women. Being hurt by this fact, in this case, the Supreme Court by emphasizing the adoption of uniform civil code in the country, remarked that, "It is a matter of regret that article 44 of our constitution has remained a dead letter... There is no evidence of any official activity for framing a uniform civil code for the country... A common civil code will help the cause of national integration by removing disparate loyalties to laws, which have conflict ideologies" (Ahmad \& Ahmad, 2006). In 1995, in the Sarla Mudgal case, the Supreme Court reiterated the need and importance of Uniform Civil Code for all citizens in India. The apex court suggested the government that the implementation of a Uniform Civil Code will protect the oppressed in the society and promote the national unity and integrity. (Manooja, 2000: 448-457) If indeed seen, the importance given to the Hindu Code Bill in the early years of independence for social reform, the more importance if the Uniform Civil Code was given and a sincere effort to implement it was made by the then government and subsequent governments. It would not have been known as a dispute today and through its medium, comprehensive reforms in Indian society and gender equality could be firmly established. But at that time not only Jawaharlal Nehru but many big leaders shied away from it, considering it unnecessary. In 1954 while answering the question of a member of Parliament, Nehru said: 
Well, I should like a civil code which applies to everybody, but...wisdom hinders...if anybody else brings forward a Civil Code Bill, it will have my extreme sympathy. But I confess I do not think that at the present moment the time is ripe in India for me to try to push it through. I want to prepare the ground for it. (Smith, 1967: 290)

In addition, Sucheta Kripalani stated that we are well aware of the recent history of our country. We know the crises we have had to deal with because of minority problems, so I believe the government is not ready for a uniform civil code right now. Another Member of Parliament, Thakur Das Bhargava said that "I do not think it would be a practical proposition to have a single code for Muslims, Jews and Christians." Because Muslim members had already opposed any tampering in their personal laws, which they themselves consider to be the command of Allah." If analysed carefully, in these statements, fear from Muslim community could be seen in the Congress leaders. Fear of communal tension, fear of dissatisfaction in Muslims and above all, the fear of electoral loss due to resentment of Muslim community. On this issue, Acharya J B Kripalani accused the government of being coward and communal, saying that:

We call our state a secular state- A secular state goes neither by scripture nor by custom. It must work on sociological and political grounds. If we are a democratic state, I submit we must make laws not for one community alone. Today the Hindu community is for monogamy.... Will our government introduce a bill for monogamy for the Muslim community? Will my dear law minister apply the part about monogamy to every community in India?... I tell you this is the democratic way. It is not the Mahasabhaites alone who are communal; it is the government also that is communal, whatever it may say. It is passing a communal measure. You shall be known by your acts, not by your profession. You have deluded the world so often with words. I charge you with communalism because you are bringing forward a law about monogamy only for the Hindu community. You must bring it also for the Muslim community ... the Muslim community is prepared to have it but you are not brave enough to do it. (Seth, 2005: 43)

Surprisingly, no government in independent India has shown the courage to legislate and implement a uniform civil code. Political parties, to appease the Muslim vote bank, could not muster the courage to do so in the last seven decades. Whenever a uniform civil code was sought to be implemented, a section of society opposed it by calling it against the secular nature of India. This protest continued to give political parties reason to not move forward on this issue.

\section{Why Protest?}

In fact, the basis of this protest is more authoritative than social or religious. Its adversaries understand that if the Uniform Civil Code is implemented, it will end the distrust that has been generated by Muslims about it, which will be politically harmful for them. Therefore, they have continuously mobilized Muslim clerics and religious leaders to oppose it, who themselves fear losing their social and religious authority. In fear of losing power, a coalition of conservative religious leaders and political leaders has been formed against the Uniform Civil Code, which has to preserve its social, political and religious authority. For this, they have made such propaganda about the Uniform Civil Code that Muslim society started to feel that with the implementation of this law, they can actually lose their social, cultural and above all, their religious identity. They have been opposing the uniform civil code in the name of secularism or right to religious freedom given in the constitution. In fact, this opposition under the guise of secularism is a reflection of the duality between 'constitutional secularism and party-political secularism' (Bhargava, 2017) ${ }^{[10]}$. Here, they forget the equality and the right to life with the utmost dignity provided in the constitution. In reality, the Uniform Civil Code provides a more robust basis for achieving the goals of secularism and religious freedom.

\section{Concluding Observations}

Today, leading Muslim countries of the world have adopted a progressive social approach and have made their personal laws more liberal and humane. Uniform Civil Code has been implemented in America and many other western countries too, while a large number of Muslims are living there. So why so much controversy in India on this issue? It is true that the call for social reforms should be from within the society itself, only after these reforms can be peaceful and permanent. But in the absence of social consciousness, the responsibility of reforms falls on the section of the country which has been chosen by the society as its representative. However, there could be an opposition to the work done by them because a section of the society, who have social dominance and political self-centredness, will never accept any interference in their socio-political status. Nevertheless, beyond such socio-political calculations, our politico-constitutional institutions will have to take some stern steps which are mandatory for the establishment of a progressive society. And when it is about the half of the population of a country, then it becomes more important that reform should be done without any delay. While doing so, it is mandatory to marginalize the voice of protests and dissatisfaction for some time. These voices were there when attempts were made to abolish Sati and child marriage and when some reforms were made to enforce widow marriages. But, if these voices were given importance at that time, these malicious practices would probably still exist today in more gruesome form than before. Since the present government has included the enactment of the Uniform Civil Code in its agenda, it is their social and moral responsibility to make positive and active efforts to implement it without giving importance to the unprincipled protests.

\section{Notes}

1. See, Lok Sabha Debates, 1955, Part 2, Volume 4, 7376.

2. See, Constitution of India

3. See, Constituent Assembly Debates, Vol. VII, p. 540541.

4. Ibid, p. 544.

5. Ibid, p. 543.

6. Ibid, p. 547.

7. Ibid, p. 550.

8. See, Constitution of India, part III, article 25

9. Ibid 
10. Rajiv Bhargava has described the basis of the ambivalence towards secularism in India as constitutional secularism and party-political secularism. According to him, party-political secularism is a strange, orthodox doctrine practiced by political parties, especially the so-called "secular forces". This secularism removed the principles from the original idea and converted them into opportunism; Its slogan is opportunistic distance from all religious communities. Whereas, India's constitutional secularism is based on the principled distance from all religions.

\section{References}

1. Ahmad S, Ahmad S. Uniform Civil Code (Article 44 of the Constitution): A Dead Letter. The Indian Journal of Political Science 2006;67(3):545-552.

2. Bhargava R. Constitutional or Party Political Secularism? 2017. Retrieved from The Hindu: https://www.thehindu.com/opinion/oped/constitutional-or-party-politicalsecularism/article19436067.ece

3. Mahajan Gurpreet. Contextualizing Secularism: The Relationship between State and Religion in India. In Peter Losonczi and Walter Van Herck, Secularism, Religion and Politics: India and Europe. New Delhi: Routledge 2015.

4. Manooja DC. Uniform Civil Code: A Suggestion. Journal of the Indian Law Institute, 2000, 448-457.

5. Mohpatra BN. Minorities and Politics. In N. G. Jayal, \& P. B. Mehta, The Oxrford Compaion to Politics in India. New Delhi: Oxford University Press 2016, 219237.

6. Seth L. A Uniform Civil Code: Towards gender justice. India International Centre Quarterly 2005;31(4):40-54.

7. Smith DE. India as a Secular State. New Jersey: Princeton University Press 1967. 